\title{
Pharmacological Study of TA-0910, a New Thyrotropin- Releasing Hormone (TRH) Analog (III): Inhibition of Pentobarbital Anesthesia
}

\author{
Michio Yamamura, Kiyoshi Kinoshita, Hiroyuki Nakagawa and Ryuichi Ishida \\ Department of Pharmacology, Safery Research Laboratory, Tanabe Seiyaku Co, Ltd., \\ 16-89, 3-chome, Kashima, Yodogawa-ku Osaka 532, Japan
}

Received July 20, 1990 Accepted October 11, 1990

\begin{abstract}
Sites and mechanisms of the antagonistic action of TA-0910, a new thyrotropin-releasing hormone (TRH) analog, on pentobarbital anesthesia were studjed in rats. Intravenous administration of TA-0910 dose-dependently shortened the duration of pentobarbital anesthesia at $30 \mu \mathrm{g} / \mathrm{kg}$ or more. The anti-anesthetic action of TA-0910 after intracerebral injection was in the following order of effectiveness: the posterior lateral hypothalamic area $>$ midbrain reticular formation $>$ raphe nuclei $=$ locus ceruleus $>$ anterior lateral hypothalamic area $=$ ventral globus pallidus $=$ hippocampus. TA-0910 injected into the nucleus accumbens, medial septal nucleus, parietal cortex or striatum had no effect, even at high doses. The anti-anesthetic action of TA-0910 $(0.1 \mathrm{mg} / \mathrm{kg}$, i.v. $)$ was inhibited by a low dose of scopolamine or mecamylamine and by a high dose of haloperidol, phenoxybenzamine or metergoline. However, physostigmine and oxotremorine showed no anti-anesthetic action alone or in combination with TA-0910 $(0.01 \mathrm{mg} / \mathrm{kg}$, i.v. $)$. Pentobarbital anesthesia was not inhibited by carbachol injected into various sites of the brain. These results suggest that the inhibitory effect of TA-0910 on pentobarbital anesthesia is mainly produced by activation of the posterior lateral hypothalamic area and the midbrain reticular formation, and that the involvements of not only acetylcholine but also other neurotransmitters such as dopamine, serotonin, and noradrenaline should be examined for their anti-anesthetic action.
\end{abstract}

A new thyrotropin-releasing hormone (TRH) analog, TA-0910 [1-methyl-(S)-4,5dihydroorotyl-L-histidyl-L-prolineamide], is about 30-100 times more potent than TRH in various central nervous system (CNS) actions, and its duration of action is about 8 times longer than that of TRH in mice and rats (1, 2). However, its thyrotropin releasing activity is about 50 times less potent than that of TRH in rats (1). We have already reported that systemically administered TA-0910 possesses a pentobarbital anesthesia-antagonizing effect in mice $(1,2)$. Of its CNS actions, in particular, the antagonistic action of TA- 0910 on pentobarbital anesthesia is the most potent, similar to TRH (3-6). The anti-anesthetic action of TRH is considered to be mediated partly by activation of the cholinergic neurons $(7-9)$. However, there have been conflicting reports about the sites and mechanisms of the antianesthetic action of TRH: Kalivas and Horita $(10,11)$ demonstrated that the anti-anesthetic action of TRH may cause arousal via activation of the cholinergic efferents from the septum to the hippocampus; Miyamoto et al. (9) suggested that the main action sites of TRH in 
the antagonism of pentobarbital-induced sleep may be the posterior hypothalamic regions, dorsomedial nucleus of the thalamus, medial septal nucleus, reticular formation and hippocampus and suggested that cholinergic mechanisms may be involved in the effect of TRH in the hypothalamus; Santori et al. (12) reported that the antimuscarinics atropine and scopolamine failed to block the anti-pentobarbital anesthesia of TRH.

We investigated the antagonistic effects of TA-0910 and TRH on pentobarbital anesthesia in rats by injecting these drugs into various sites of the brain both alone and in combination with various kinds of CNS agents, to elucidate the sites and mechanisms of the antianesthetic action of TA-0910 as well as those of TRH.

\section{MATERIALS AND METHODS}

\section{Animals}

Male Slc: Wistar rats each weighing $180-$ $200 \mathrm{~g}$ were used. Each rat was housed in one compartment $(15 \times 25 \times 14 \mathrm{~cm})$ of a stainless steel 5-compartment wire-mesh cage $(75 \times 25$ $\times 14 \mathrm{~cm}$, mesh: $6 \mathrm{~mm}$ ). The animals were kept in an animal room maintained at $23 \pm$ $1{ }^{\circ} \mathrm{C}$ with $55 \pm 5 \%$ humidity and illuminated for $12 \mathrm{hr}(6: 30-18: 30)$. The rats were allowed free access to pellet diets (CRF-1, Oriental Yeast) and tap water.

\section{Drugs}

TA-0910 (1-methyl-(S)-4,5-dihydroorotyl-Lhistidyl-L-prolineamide tetrahydrate, Lot No. 503090] and TRH (L-pyroglutamyl-L-histidylL-prolineamide-L-tartrate monohydrate: Lot No. 114119A) were synthesized in the Research Laboratory of Applied Biochemistry, Tanabe Seiyaku Co., Ltd. Other drugs used for the study were: pentobarbital sodium (Nacalai Tesque), scopolamine hydrobromide (Sigma), mecamylamine hydrochloride (Sigma), metergoline (Farmitalia Carlo Erba), haloperidol (Dainihon), phenoxybenzamine hydrochloride (Tokyo Kasei), physostigmine (Eserin ${ }^{(8)}$, Merck), oxotremorine sesquifuma- rate (Aldrich), and carbamylcholine chloride (Carbachol $^{\mathrm{B}}$, Sigma). All the drugs were dissolved in physiological saline except for metergoline, which was suspended in $0.5 \%$ carboxymethyl cellulose sodium (CMC), and haloperidol, which was dissolved in distilled water.

\section{Administration of drugs}

TA-0910 and TRH were administered intravenously (i.v.) at $2 \mathrm{ml} / \mathrm{kg}$ and intracerebrally (i.c.) at the volume of $5 \mu \mathrm{l}$ on each side 10 min after intraperitoneal (i.p.) administration of pentobarbital $(60 \mathrm{mg} / \mathrm{kg})$. The muscarinic ACh receptor antagonist scopolamine $(1,3$ $\mathrm{mg} / \mathrm{kg}$ ) and nicotinic $\mathrm{ACh}$ receptor antagonist mecamylamine $(10,30 \mathrm{mg} / \mathrm{kg})$, dopamine receptor antagonist haloperidol $(0.1,0.3$ $\mathrm{mg} / \mathrm{kg}), \quad \alpha$-adrenaline receptor antagonist phenoxybenzamine $(0.5,2 \mathrm{mg} / \mathrm{kg})$, and 5 -HT receptor antagonist metergoline $(0.2,1 \mathrm{mg} / \mathrm{kg})$ were administered intraperitoneally $30 \mathrm{~min}$ before administration of pentobarbital. The acetylcholinesterase inhibitor physostigmine $(0.1-1 \mathrm{mg} / \mathrm{kg})$ and the muscarinic ACh receptor agonist oxotremorine $(0.1,0.3 \mathrm{mg} / \mathrm{kg})$ were administered intraperitoneally 15 and 10 min, respectively, before pentobarbital administration. The muscarinic ACh agonist carbachol ( $2 \mu \mathrm{g} /$ brain) was injected intracerebrally $10 \mathrm{~min}$ after pentobarbital administration. The volume of i.p. injection was $5 \mathrm{ml} / \mathrm{kg}$ for pentobarbital but $2 \mathrm{ml} / \mathrm{kg}$, i.v. or i.p., for the other drugs. The control rats were given an equal volume of physiological saline.

\section{Measurement of duration of pentobarbital anes-} thesia

Anesthesia was considered to have been established by the loss of the righting reflex, and the duration of anesthesia was measured from $10 \mathrm{~min}$ after pentobarbital $(60 \mathrm{mg} / \mathrm{kg}$, i.p.) administration (animals that showed the righting reflex at this time were excluded) to the recovery of the righting reflex. All experiments were carried out between 9:00 and 18:00 in a sound-proof room. 
Table 1. Stereotaxic coordinates of injection sites

\begin{tabular}{lccr}
\hline \multirow{2}{*}{ Injection sites } & \multicolumn{3}{c}{ Stereotaxic coordinates $^{\text {a) }}$} \\
\cline { 2 - 4 } & A & \multicolumn{1}{c}{. } & H \\
\hline Nucleus accumbens & 9.2 & 1.5 & 0.0 \\
Medial septal nucleus & 7.8 & 0.0 & 0.8 \\
Parietal cortex & 7.0 & 3.0 & 5.2 \\
Anterior lateral hypothalamic area & 7.0 & 2.0 & -1.7 \\
Ventral globus pallidas & 6.4 & 2.8 & -1.0 \\
Posterior lateral hypothalamic area & 4.6 & 1.8 & -3.2 \\
Hippocampus & 3.2 & 2.5 & 2.0 \\
Midbrain reticular formation & 1.0 & 1.5 & -2.5 \\
Raphe nuclei & -2.2 & 0.0 & -6.3 \\
Locus ceruleus & -1.5 & 1.3 & -3.3 \\
Caudate nucleus-putamen (Striatum) & 7.8 & 3.0 & 1.0 \\
\hline
\end{tabular}

a)"A stereotaxic atlas of the rat brain" by Pellegrino and Cushman (13).

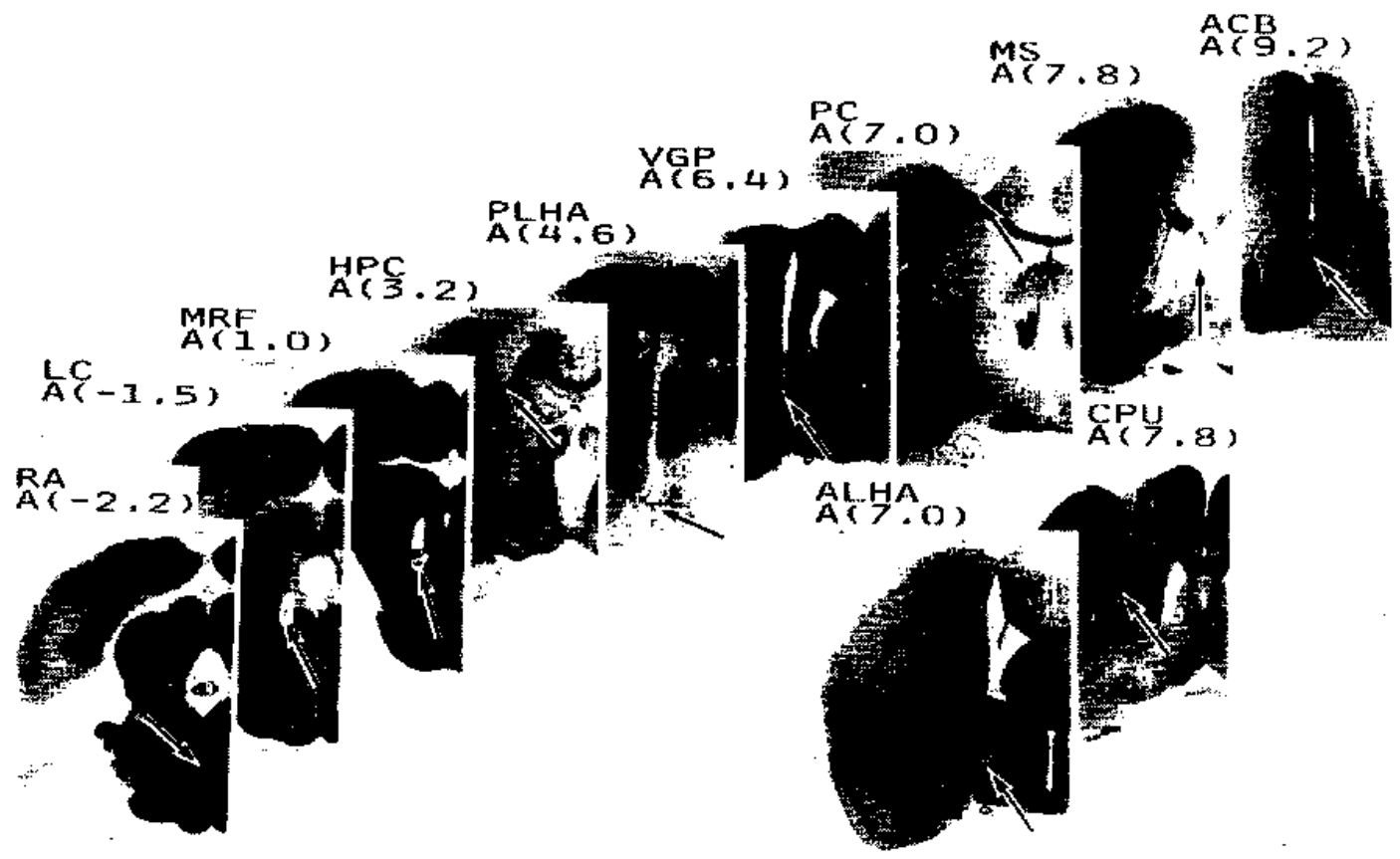

Fig. 1. Photomicrograph of locations of the cannula tips for intracerebral injection, according to the atlas of Pellegrino and Cushman. Abbreviations: ACB: nucleus accumbens, MS: Medial septal nucleus, CPU: Caudate nucleus-putamen (Striatum), PC: Parietal cortex, ALHA: Anterior lateral hypothalamic area, VGP: Ventral globus pallidas, PLHA: Posterior lateral hypothalamic area, HPC: Hippocampus, MRF: Midbrain reticular formation, LC: Locus ceruleus, RA: Raphe nucleus. 
Implantation of a guide cannula for microinjection of drugs into the brain

The rats were fixed in a stereotaxic instrument (Narishige, ST-7) under pentobarbital anesthesia $(50 \mathrm{mg} / \mathrm{kg}$, i.p. $)$. A stainless steel guide cannula $(0.5-\mathrm{mm}$ outer and $0.25-\mathrm{mm}$ inner diameters) was implanted $1 \mathrm{~mm}$ above the target injection site according to the brain atlas of Pellegrino and Cushman (13) and fixed onto the skull with screws and dental cement. Table 1 shows the stereotaxic coordinates of the 11 injection sites. The guide cannulas for the medial septal nucleus and raphe nuclei were implanted on the midline and those for the other sites, bilaterally. A stainless steel injection cannula (0.2-mm outer and $0.08-\mathrm{mm}$ inner diameters) was inserted into the guide cannula, and the drug solution was injected at a volume of $1 \mu l$ into the medial septal nucleus and raphe nuclei and $0.5 \mu \mathrm{l}$ on each side of the other sites, at a rate of 0.5 $\mu \mathrm{l} / 30 \mathrm{sec}$ using a microsyringe (TERMO ${ }^{\mathrm{f}}$ ). After injection, a stainless steel stylet $(0.2-\mathrm{mm}$ outer diameter) was inserted $0.5 \mathrm{~mm}$ deeper than the tip of the guide cannula to prevent its occlusion by infiltration of blood or tissue fluid. The rats were used repeatedly at 1 -week intervals from 7 days after cannulation.

Verification of the site of cannula implantation

At the end of all experiments, the rats with implanted guide cannula were perfused with $10 \%$ formalin solution through the left cardiac ventricle under pentobarbital $(40 \mathrm{mg} / \mathrm{kg}$, i.p.) anesthesia. The brain was removed and kept in $10 \%$ formalin solution for at least 7 days and then sectioned to verify the site of cannulation under binoculars. The tip of each guide cannula for i.c. injection was confirmed to have been placed in the proper site of the brain (Fig. 1).

\section{Statistical analysis}

The values obtained were expressed in the tables as the mean standard error. The differences were examined first by the Kruskal-Wallis test and then by Scheffé type multiple comparison or the Mann-Whitney $U$-test.

\section{RESULTS}

Inhibition of pentobarbital anesthesia by intravenous administration of TA-0910 or TRH

TA-0910 and TRH dose-dependently and significantly shortened the duration of anesthesia at $0.03 \mathrm{mg} / \mathrm{kg}$ or more and $10 \mathrm{mg} / \mathrm{kg}$ or more, respectively (Table 2). From the minimal effective doses, the anti-anesthetic action of TA- 0910 is considered to be about 300 times more potent than that of TRH.

Table 2. Effects of TA-0910 and TRH on pentobarbital anesthesia in rats

\begin{tabular}{lcccc}
\hline Drugs & $\begin{array}{c}\text { Dose } \\
\text { (mg/kg, i.v.) }\end{array}$ & N & $\begin{array}{c}\text { Duration of anesthesia } \\
\text { (min, Mean } \pm \text { S.E.) }\end{array}$ & $\begin{array}{c}\text { Shortening } \\
(\%)\end{array}$ \\
\hline Saline & - & 9 & $88.0 \pm 4.2$ & - \\
TA-0910 & 0.003 & 8 & $81.5 \pm 2.3$ & 7.4 \\
& 0.01 & 8 & $79.8 \pm 4.4$ & 9.3 \\
& 0.03 & 9 & $66.3 \pm 2.9^{*}$ & 24.7 \\
& 0.1 & 9 & $62.4 \pm 5.6^{* *}$ & 29.1 \\
TRH & 0.3 & 10 & $80.3 \pm 4.3$ & 8.8 \\
& 1 & 11 & $77.0 \pm 6.6$ & 12.5 \\
& 3 & 9 & $74.5 \pm 5.3$ & 15.3 \\
& 10 & 8 & $55.7 \pm 3.2^{* *}$ & 36.7 \\
\hline
\end{tabular}

${ }^{*} \mathrm{P}<0.05,{ }^{* *} \mathrm{P}<0.01$ : Significantly different from the value for the control group (Scheffés multiple comparison test). 
Table 3. Effects of TA-0910 injected into various brain sites on pentobarbital anesthesia in rats

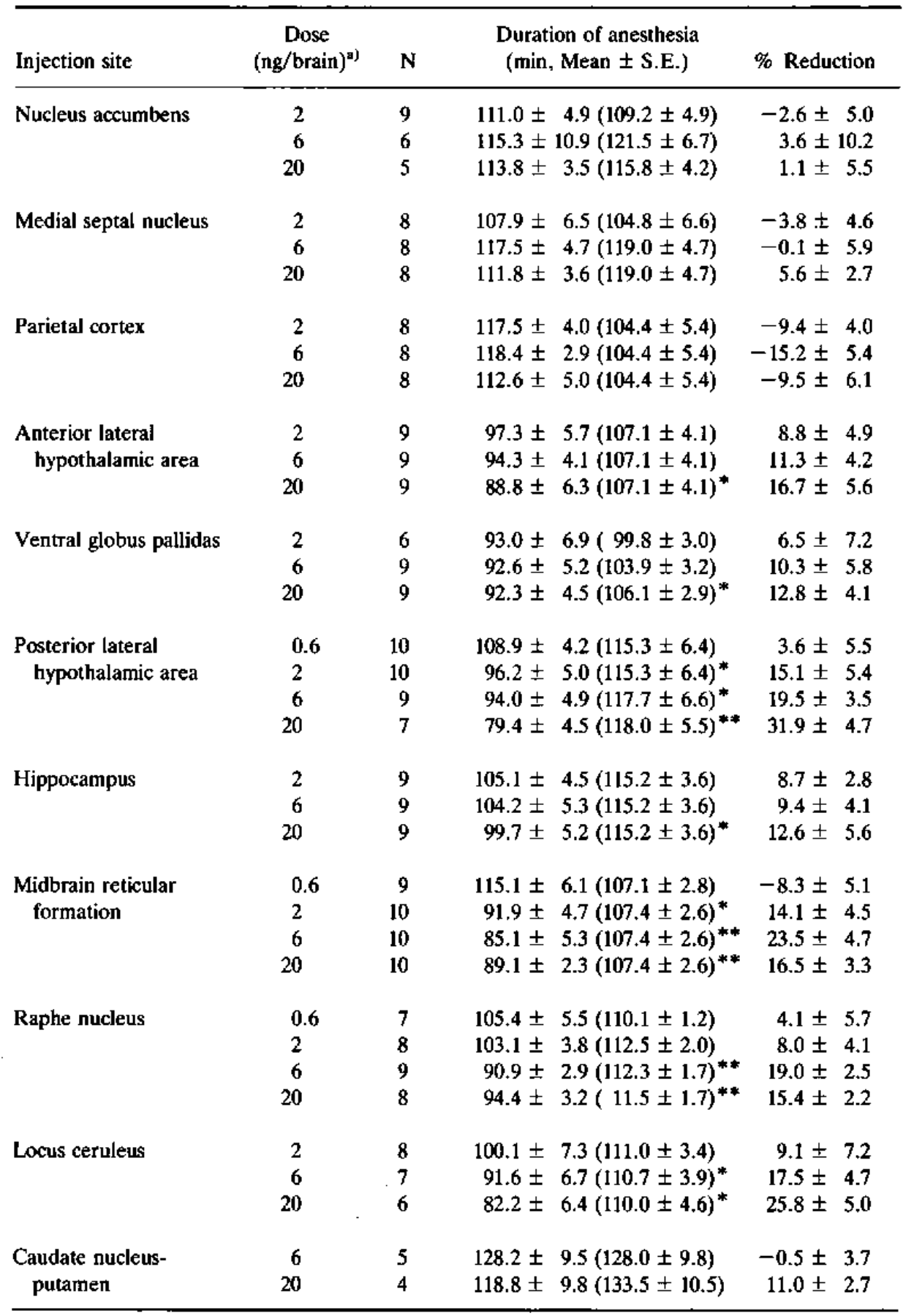

( ): The corresponding control (saline alone). ${ }^{*} \mathrm{P}<0.05,{ }^{* *} \mathrm{P}<0.01$ : Significantly different

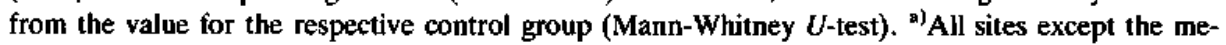
dial septal nucleus and raphe nucleus were injected bilaterally. 
Table 4. Effects of TRH injected into various brain sites on pentobarbital anesthesia in rats

\begin{tabular}{|c|c|c|c|c|c|}
\hline Injection site & $\begin{array}{c}\text { Dose } \\
(\mu \mathrm{g} / \text { brain })^{a)}\end{array}$ & $\mathrm{N}$ & $\begin{array}{l}\text { Durati } \\
\text { (min, }\end{array}$ & $\begin{array}{l}\text { ion of anesthesia } \\
\text { Mean } \pm \text { S.E.) }\end{array}$ & \% Reduction \\
\hline \multirow[t]{3}{*}{ Nucleus accumbens } & 6 & 8 & $116.4 \pm$ & $5.6(126.3 \pm 5.4)$ & $7.5 \pm 4.6$ \\
\hline & 20 & 6 & $106.2 \pm$ & $6.0(118.8 \pm 3.1)$ & $10.7 \pm 4.2$ \\
\hline & 60 & 10 & $106.9 \pm$ & $5.1(126.9 \pm 3.8)^{*}$ & $15.3 \pm 4.3$ \\
\hline \multirow[t]{3}{*}{ Medial septal nucleus } & 6 & 7 & $134.6 \pm$ & $6.9(120.9 \pm 7.8)$ & $-13.6 \pm 5.9$ \\
\hline & 20 & 7 & $118.0 \pm$ & $2.8(120.9 \pm 7.8)$ & $0.0 \pm 6.5$ \\
\hline & 60 & 7 & $117.6 \pm$ & $8.6(132.0 \pm 3.1)$ & $11.2 \pm 5.4$ \\
\hline \multirow[t]{3}{*}{ Parietal cortex } & 6 & 8 & $131.8 \pm$ & $2.4(127.5 \pm 3.3)$ & $-3.7 \pm 2.3$ \\
\hline & 20 & 8 & $126.3 \pm$ & $3.1(127.5 \pm 3.3)$ & $0.3 \pm 4.3$ \\
\hline & 60 & 8 & $129.5 \pm$ & $4.5(127.5 \pm 3.3)$ & $-1.8 \pm 3.3$ \\
\hline \multirow{3}{*}{$\begin{array}{l}\text { Anterior lateral } \\
\text { hypothalamic area }\end{array}$} & 2 & 9 & $116.4 \pm$ & $4.0(110.8 \pm 4.2)$ & $-6.0 \pm 6.2$ \\
\hline & 6 & 9 & $98.8 \pm$ & $3.0(110.8 \pm 4.2)^{*}$ & $9.1 \pm 6.2$ \\
\hline & 20 & 10 & $88.1 \pm$ & $1.7(109.0 \pm 4.1)^{* *}$ & $18.3 \pm 3.0$ \\
\hline \multirow[t]{3}{*}{ Ventral globus pallidas } & 6 & 9 & $107.2 \pm$ & $4.5(121.0 \pm 3.7)$ & $11.2 \pm 3.2$ \\
\hline & 20 & 9 & $107.3 \pm$ & $6.3(121.0 \pm 3.7)$ & $10.5 \pm 6.0$ \\
\hline & 60 & 9 & $101.6 \pm$ & $3.5(121.0 \pm 3.7)^{* *}$ & $15.9 \pm 3.3$ \\
\hline \multirow{4}{*}{$\begin{array}{l}\text { Posterior lateral } \\
\text { hypothalamic area }\end{array}$} & 0.6 & 8 & $122.9 \pm$ & $4.8(111.1 \pm 5.6)$ & $-11.7 \pm 4.8$ \\
\hline & 2 & 10 & $109.9 \pm$ & $4.2(127.6 \pm 6.0)^{*}$ & $12.1 \pm 5.2$ \\
\hline & 6 & 10 & $101.9 \pm$ & $2.5(127.6 \pm 6.0)^{* *}$ & $18.1 \pm 5.3$ \\
\hline & 20 & 10 & $96.4 \pm$ & $8.6(127.6 \pm 6.0)^{*}$ & $23.8 \pm 5.9$ \\
\hline \multirow[t]{3}{*}{ Hippocampus } & 6 & 9 & $126.9 \pm$ & $4.5(125.9 \pm 4.1)$ & $-1.7 \pm 4.8$ \\
\hline & 20 & 10 & $103.3 \pm$ & $3.1(128.2 \pm 4.3)^{* *}$ & $18.3 \pm 4.3$ \\
\hline & 60 & 9 & $108.8 \pm$ & $4.3(125.9 \pm 4.1)^{*}$ & $14.8 \pm 4.1$ \\
\hline \multirow{3}{*}{$\begin{array}{l}\text { Midbrain reticular } \\
\text { formation }\end{array}$} & 6 & 10 & $111.7 \pm$ & $4.5(118.5 \pm 5.1)$ & $5.3 \pm 2.6$ \\
\hline & 20 & 10 & $93.9 \pm$ & $3.6(118.5 \pm 5.1)^{* *}$ & $19.9 \pm 3.6$ \\
\hline & 60 & 9 & $102.3 \pm$ & $4.1(119.4 \pm 5.4)^{*}$ & $13.9 \pm 3.1$ \\
\hline \multirow[t]{3}{*}{ Raphe nucleus } & 2 & 10 & $120.8 \pm$ & $3.4(126.9 \pm 4.9)$ & $4.3 \pm 2.2$ \\
\hline & 6 & 10 & $110.7 \pm$ & $3.4(126.9 \pm 4.9)^{*}$ & $11.9 \pm 3.5$ \\
\hline & 20 & 10 & $102.6 \pm$ & $3.5(126.9 \pm 4.9)^{* *}$ & $18.6 \pm 2.7$ \\
\hline \multirow[t]{3}{*}{ Locus ceruleus } & 6 & 7 & $121.3 \pm$ & $8.1(123.7 \pm 8.4)$ & $1.1 \pm 4.9$ \\
\hline & 20 & 9 & $103.2 \pm$ & $5.3(116.8 \pm 8.1)$ & $9.3 \pm 5.7$ \\
\hline & 60 & 7 & $123.2 \pm$ & $6.3(126.2 \pm 9.5)$ & $-0.1 \pm 7.8$ \\
\hline \multirow{3}{*}{$\begin{array}{l}\text { Caudate nucleus- } \\
\text { putamen }\end{array}$} & 6 & 5 & $137.4 \pm$ & $6.5(139.2 \pm 4.0)$ & $1.0 \pm 5.5$ \\
\hline & 20 & 7 & $141.9 \pm$ & $11.8(141.6 \pm 4.5)$ & $0.2 \pm 6.9$ \\
\hline & 60 & 6 & $139.3 \pm$ & $3.8(143.0 \pm 5.0)$ & $0.3 \pm 2.9$ \\
\hline
\end{tabular}

( ): The corresponding control (saline alone). ${ }^{*} \mathrm{P}<0.05,{ }^{* *} \mathrm{P}<0.01$ : Significantly different

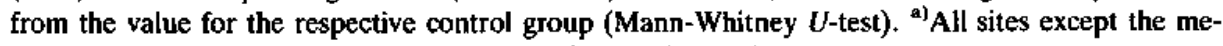
dial septal nucleus and raphe nucleus were injected bilaterally. 
Inhibition of pentobarbital anesthesia by intracerebral injection of TA-0910 or TRH

In each site on injection of TA-0910, no significant difference in the duration of pentobarbital anesthesia was observed among the saline-treated control groups by Sheffe type multiple comparison test (Table 3 ). The duration of pentobarbital anesthesia was signifi- cantly shortened by injection of $2 \mathrm{ng}$ or more of TA-0910 into the posterior lateral hypothalamic area and midbrain reticular formation; the action was more remarkable in the former site than in the latter site. Injection into the raphe nuclei or locus celluleus also reduced the duration of anesthesia at comparatively low doses (6 ng or more). When injected into

Table 5. Effects of various kinds of CNS agents on the anti-pentobarbital anesthetic action of TA-0910 in rats

\begin{tabular}{|c|c|c|c|c|c|}
\hline \multicolumn{2}{|c|}{ Pretreatment } & \multirow{2}{*}{$\mathbf{N}$} & \multirow{2}{*}{$\begin{array}{c}\text { TA-0910 } \\
(0.1 \mathrm{mg} / \mathrm{kg}, \mathrm{i} . \mathrm{v} .)\end{array}$} & \multirow{2}{*}{\multicolumn{2}{|c|}{$\begin{array}{c}\text { Duration of anesthesia } \\
\text { (min, Mean } \pm \text { S.E.) }\end{array}$}} \\
\hline Drugs & Dose (mg/kg, i.p.) & & & & \\
\hline \multirow[t]{2}{*}{ Saline } & - & 9 & - & $99.5 \pm 6.9-$ & ** \\
\hline & - & 10 & + & $67.8 \pm 3.3$ & $T$ \\
\hline \multirow[t]{4}{*}{ Scopolamine } & 1 & 10 & $\rightarrow$ & $100.7 \pm 4.8$ & $\# \#$ \\
\hline & 1 & 10 & + & $82.9 \pm 3.5$ & \\
\hline & 3 & 10 & - & $125.9 \pm 2.5$ & \\
\hline & 3 & 10 & + & $112.8 \pm 3.1$ & \\
\hline \multirow[t]{2}{*}{ Saline } & - & 10 & - & $105.6 \pm 3.3$ & 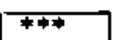 \\
\hline & - & 9 & + & $81.9 \pm 2.9$ & 7 \\
\hline \multirow[t]{4}{*}{ Mecamylamine } & 10 & 9 & - & $117.0 \pm 6.6$ & \#\# \\
\hline & 10 & 10 & + & $109.0 \pm 4.0$ & \\
\hline & 30 & 10 & - & $140.0 \pm 7.6$ & \\
\hline & 30 & 11 & + & $126.5 \pm 5.3$ & \\
\hline \multirow[t]{2}{*}{ Saline } & - & 10 & - & $90.5 \pm 4.0$ & $* * * *$ \\
\hline & - & 10 & + & $68.2 \pm 2.8$ & \\
\hline \multirow[t]{4}{*}{ Haloperidol } & 0.1 & 10 & - & $89.0 \pm 3.0$ & \\
\hline & 0.1 & 9 & + & $65.8 \pm 3.5$ & it \\
\hline & 0.3 & 10 & - & $129.3 \pm 4.1$ & \\
\hline & 0.3 & 9 & + & $109.1 \pm 4.1$ & \\
\hline \multirow[t]{2}{*}{ Saline } & - & 10 & - & $91.5 \pm 2.4$ & $\overline{* * *}$ \\
\hline & - & 10 & + & $54.5 \pm 2.9$ & \\
\hline \multirow{4}{*}{$\begin{array}{l}\text { Phenoxybenz- } \\
\text { amine }\end{array}$} & 0.5 & 10 & - & $88.6 \pm 4.6$ & \\
\hline & 0.5 & 10 & + & $57.1 \pm 3.0$ & \\
\hline & 2 & 7 & - & $133.3 \pm 17.7$ & \\
\hline & 2 & 10 & + & $85.2 \pm 3.9$ & \\
\hline \multirow[t]{2}{*}{ Saline } & - & 11 & - & $91.5 \pm 2.4$ & $\# *$ \\
\hline & $\overline{02}$ & 10 & + & $\begin{array}{l}69.1 \pm 2.3 \\
018+34\end{array}$ & \\
\hline \multirow{3}{*}{ Metergoline } & $\begin{array}{l}0.2 \\
0.2\end{array}$ & $\begin{array}{l}10 \\
10\end{array}$ & + & $\begin{array}{l}91.8 \pm 3.4 \\
68.5 \pm 3.4\end{array}$ & + \\
\hline & 1 & 10 & - & $111.4 \pm 4.9$ & \\
\hline & 1 & 10 & + & $92.8 \pm 5.5$ & \\
\hline
\end{tabular}

${ }^{* *} \mathrm{P}<0.01,{ }^{* * *} \mathrm{P}<0.001:$ Significantly different from the value for the respective saline-TA-0910 (-) (Mann-Whitney $U$-test). ${ }^{+} \mathrm{P}<0.05,{ }^{++} \mathrm{P}<0.01$ : Significantly different from the value for the respective saline-TA-0910 (+) (Scheffés multiple comparison test). ${ }^{\#} \mathrm{P}<0.05$, \#\# $\mathrm{P}<0.01$ : Significantly different from the value for the respective saline-TA-0910 (-) (Scheffé's multple comparison test). 
the anterior lateral hypothalamic area, ventral globus pallidus and hippocampus, the antianesthetic action of TA-0910 was less potent, because a high dose $(20 \mathrm{ng})$ of TA- 0910 was required to evoke the effect. TA- 0910 injected into the nucleus accumbens, medial septal nucleus, parietal cortex, or striatum had no effect, even at $20 \mathrm{ng}$ (Table 3).

In each site of TRH injection, no significant difference in the duration of pentobarbital anesthesia was observed among the salinetreated control groups by Sheffé type multiple comparison test (Table 4). The anti-anesthetic action of TRH $(0.6-60 \mu \mathrm{g}$, like that of TA0910, was particularly marked in the case of injection into the posterior lateral hypothalamic area. The anti-anesthetic action of TRH after injection into other sites was in the following order of effectiveness: raphe nuclei $=$ anterior lateral hypothalamic area $>$ hippocampus $=$ midbrain reticular formation $>$ nucleus accumbens $=$ ventral globus pallidus. On the other hand, TRH $(60 \mu \mathrm{g})$ injected into the medial septal nucleus, parietal cortex, locus ceruleus, or corpus striatum had no effect (Table 4). From the minimal effective doses after injection into the posterior lateral hypothalamic area, the anti-anesthetic action of TA- 0910 was considered to be about 1,000 times more potent than that of TRH.

Effects of various kinds of CNS agents on the inhibitory action of TA-0910 in pentobarbital anesthesia

The anti-anesthetic action of TA-0910 (0.1 $\mathrm{mg} / \mathrm{kg}$, i.v.) was markedly antagonized by i.p. pretreatment with scopolamine and mecamylamine at doses that produced no significant change in pentobarbital anesthesia. On the other hand, haloperidol, phenoxybenzamine, and metergoline inhibited the anti-anesthetic action of TA- 0910 only at the doses at which they significantly prolonged the duration of pentobarbital anesthesia (Table 5). However, physostigmine $(0.1-1 \mathrm{mg} / \mathrm{kg}$, i.p. $)$ and oxotremorine $(0.1,0.3 \mathrm{mg} / \mathrm{kg}$, i.p.) showed no antianesthetic action alone or in combination with TA-0910 at a dose which alone has no effect

Table 6. Effects of physostigmine and oxotremorine on pentobarbital anesthesia in rats

\begin{tabular}{lccc}
\hline Drugs & $\begin{array}{c}\text { Dose } \\
(\mathrm{mg} / \mathrm{kg}, \text { i.p. })\end{array}$ & $\mathrm{N}$ & $\begin{array}{c}\text { Duration of anesthesia } \\
(\mathrm{min}, \text { Mean } \pm \text { S.E. })\end{array}$ \\
\hline Saline & - & 10 & $96.4 \pm 3.37$ \\
Physostigmine & 0.1 & 10 & $92.4 \pm 3.28$ \\
& 0.3 & 10 & $94.3 \pm 4.67$ \\
Saline & 1.0 & 10 & $90.0 \pm 3.06$ \\
Oxotremorine & - & 11 & $94.9 \pm 2.80$ \\
& 0.1 & 10 & $90.8 \pm 2.87$ \\
& 0.3 & 10 & $89.9 \pm 3.24$ \\
\hline
\end{tabular}

Table 7. Combined effect of physostigmine or oxotremorine with TA-0910 on pentobarbjtal anesthesia in rats

\begin{tabular}{|c|c|c|c|c|}
\hline \multicolumn{2}{|c|}{ Pretreatment } & \multirow{2}{*}{$\mathbf{N}$} & \multirow{2}{*}{$\begin{array}{c}\text { TA-0910 } \\
(0.01 \mathrm{mg} / \mathrm{kg}, \text { i.v. })\end{array}$} & \multirow{2}{*}{$\begin{array}{l}\text { Duration of anesthesia } \\
\text { (min, Mean } \pm \text { S.E.) }\end{array}$} \\
\hline Drugs & Dose (mg/kg, i.p.) & & & \\
\hline \multirow[t]{2}{*}{ Saline } & - & 10 & - & $86.4 \pm 2.4$ \\
\hline & - & 8 & + & $86.6 \pm 6.7$ \\
\hline Physostigmine & 1.0 & 9 & + & $90.3 \pm 2.0$ \\
\hline Oxotremorine & 0.3 & 10 & + & $84.9 \pm 3.8$ \\
\hline
\end{tabular}


on pentobarbital anesthesja (Tables 6 and 7). In addition to this, a sufficient dose $(2 \mu \mathrm{g})$ of carbachol showed no anti-anesthetic action by injection into any site of the brain including the posterior lateral hypothalamic area. Injection of carbachol into the midbrain reticular formation slightly potentiated the pentobarbital anesthesia rather than reduce it (Table 8).

\section{DISCUSSION}

The new TRH analog TA-0910 significantly inhibited pentobarbital anesthesia at a minimum dose of $30 \mu \mathrm{g} / \mathrm{kg}$, i.v., in rats. In contrast, TRH required about a 300 times higher dose than TA-0910 to antagonize pentobarbital anesthesia. Since TRH produces an antagonistic effect on pentobarbital anesthesia in hypophysectomized animals and thyroid hormones such as triiodothyronine $\left(\mathrm{T}_{3}\right)$ and tyroxine $\left(\mathrm{T}_{4}\right)$ have no anti-anesthetic effect, the anti-anesthetic action of TRH is not considered to be related to the hypophyseal-thyroid axis $(14,15)$. Miyamoto et al. (9) demonstrated that TRH produced an anti-anesthetic effect in rats at about a 10,000 times lower dose $(5 \mu \mathrm{g})$ when injected in the posterior lateral hypothalamic area than when injected i.v. and concluded that this effect is produced centrally. The pharmacokinetic study after in-

Table 8. Effects of carbachol injected into various brain sites on pentobarbital anesthesia in rats

\begin{tabular}{|c|c|c|c|c|}
\hline Injection site & $\begin{array}{c}\text { Dose } \\
\left.(\mu \mathrm{g} / \text { brain })^{\mathrm{a}}\right)\end{array}$ & $\mathbf{N}$ & $\begin{array}{l}\text { Duration of anesthesia } \\
\text { (min, Mean } \pm \text { S.E.) }\end{array}$ & $\%$ Reduction \\
\hline Nucleus accumbens & $\overline{2}$ & $\begin{array}{l}9 \\
9\end{array}$ & $\begin{array}{l}127.7 \pm 4.2 \\
128.0 \pm 5.6\end{array}$ & $-0.4 \pm 3.6$ \\
\hline Medial septal nucleus & $\frac{-}{2}$ & $\begin{array}{l}7 \\
7\end{array}$ & $\begin{array}{l}132.0 \pm 3.1 \\
127.4 \pm 2.9\end{array}$ & $3.2 \pm 3.0$ \\
\hline Parietal cortex & $\overline{2}$ & $\begin{array}{l}9 \\
9\end{array}$ & $\begin{array}{l}125.8 \pm 3.4 \\
134.7 \pm 4.1\end{array}$ & $-7.2 \pm 2.3$ \\
\hline $\begin{array}{l}\text { Anterior lateral } \\
\text { hypothalamic area }\end{array}$ & $\frac{-}{2}$ & $\begin{array}{l}5 \\
5\end{array}$ & $\begin{array}{l}111.8 \pm 6.8 \\
118.6 \pm 5.1\end{array}$ & $-8.0 \pm 8.6$ \\
\hline Ventral globus pallidas & $\overline{2}$ & $\begin{array}{l}8 \\
8\end{array}$ & $\begin{array}{l}123.5 \pm 3.1 \\
121.3 \pm 3.8\end{array}$ & $1 . \overline{ \pm} 4.5$ \\
\hline $\begin{array}{l}\text { Posterior lateral } \\
\text { hypothalamic area }\end{array}$ & $\overline{2}$ & $\begin{array}{l}8 \\
8\end{array}$ & $\begin{array}{l}130.6 \pm 4.0 \\
122.5 \pm 2.8\end{array}$ & $6.1 \pm 4.5$ \\
\hline Hippocampus & $\overline{2}$ & $\begin{array}{l}9 \\
9\end{array}$ & $\begin{array}{l}125.9 \pm 4.1 \\
128.7 \pm 5.4\end{array}$ & $-3.0 \pm 5.1$ \\
\hline $\begin{array}{l}\text { Midbrain reticular } \\
\text { formation }\end{array}$ & $\overline{2}$ & $\begin{array}{l}9 \\
9\end{array}$ & $\begin{array}{l}121.3 \pm 4.7 \\
134.8 \pm 3.2^{*}\end{array}$ & $-12.4 \pm 4.8$ \\
\hline Raphe nucleus & $\frac{-}{2}$ & $\begin{array}{l}8 \\
8\end{array}$ & $\begin{array}{l}129.4 \pm 5.2 \\
142.9 \pm 5.1\end{array}$ & $-11.5 \pm 5.5$ \\
\hline Locus ceruleus & $\overline{2}$ & $\begin{array}{l}6 \\
6\end{array}$ & $\begin{array}{l}128.3 \pm 8.1 \\
138.7 \pm 3.2\end{array}$ & $-10.1 \pm 7.2$ \\
\hline $\begin{array}{l}\text { Caudate nucleus- } \\
\text { putamen }\end{array}$ & $\overline{2}$ & $\begin{array}{l}5 \\
5\end{array}$ & $\begin{array}{l}145.8 \pm 5.1 \\
158.0 \pm 8.9\end{array}$ & $-8.5 \pm 5.2$ \\
\hline
\end{tabular}

*P < 0.05: Significantly different from the value for the respective control group (Mann-Whitney $U$ test). a) All sites except the medial septal nucleus and raphe nucleus were injected bilaterally. 
travenous administration of $\left[{ }^{14} \mathrm{C}\right]-\mathrm{TA}-0910$ (1 $\mathrm{mg} / \mathrm{kg})$ in rats revealed that about $0.02 \%(44$ ng) of TA-0910 administered was recovered from the brain ( $S$. Furuuchi, unpublished data). In our present study, TA-0910 produced an anti-anesthetic effect at $30 \mu \mathrm{g} / \mathrm{kg}$ or more when administered intravenously and at $2 \mathrm{ng}$ or more, when administered intracerebrally. Therefore, TA-0910 like TRH, is considered to produce its anti-anesthetic effect via the CNS.

TA-0910 significantly produced an anti-anesthetic effect from a low dose of $2 \mathrm{ng}$ when injected into the posterior lateral hypothalamic area and midbrain reticular fomation. This effect was remarkable and dose-dependent when the agent was administered into the former site. This suggests that the main sites for the anti-anesthetic action of TA-0910 are in the hypothalamic and midbrain reticular activating systems.

On the other hand, TRH, as did TA-0910, showed an anti-anesthetic action at the lowest dose $(2 \mu \mathrm{g})$ when injected into the posterior lateral hypothalamic area. Although the antianesthetic effect of TRH was slightly different from that of TA-0910 after injection into the nucleus accumbens and locus ceruleus, it was similar to that of TA-0910 after injection into the other sites. Thus, the main sites for the anti-anesthetic action of TA-0910 are considered to be nearly identical to those of TRH. Our view is consistent with that of Miyamoto et al. (9) who suggested that the main sites for the anti-anesthetic action of TRH are the posterior lateral hypothalamic area and the midbrain reticular formation. In contrast, Carino et al. (16) observed marked anti-anesthetic action by injection of TRH into either the rabbit cerebral cortex, caudate nucleus, thalamus, hypothalamus, preoptic region, or cerebellum and suggested that the sites of this action are in a wide area of the brain. On the basis of the findings after injection of TRH into various sites of the rat brain, Kalivas and Horita (10) suggested the medial septal nucleus, interpeduncular nucleus, medial thalamus, and paraventricular gray matter of the thalamus to be the sites of the anti-anesthetic action of TRH, emphasizing the particular importance of the septal-hippocampal system that is rich in cholinergic neurons. In our present study, TA-0910 also produced an antianesthetic action at relatively low doses $(6 \mathrm{ng}$ or more ) when injected into the raphe nuclei and locus ceruleus, and at relatively high doses (20 ng or more) when injected into the ventral globus pallidus and hippocampus, suggesting that systemically administered TA-0910 will exhibit some type of anti-anesthetic action by acting on a wide area of the brain. Since pentobarbital globally suppresses the CNS (17), there is a fair possibility of TA-0910 or TRH antagonizing anesthesia to some extent when injected into any site of the brain. However, since pentobarbital is thought to markedly suppress the hypothalamus and the ascending reticular activating system among various sites of the central nervous system (18, 19), the posterior lateral hypothalamic area and the midbrain reticular formation are likely to be the main sites of action of TA-0910 and TRH in producing their antagonisms against pentobarbital anesthesia.

The anti-anesthetic effect of intravenous administration of TA-0910 was specifically inhibited by pretreatment with scopolamine or mecamylamine at doses producing no effect on pentobarbital anesthesia or with haloperidol $(0.3 \mathrm{mg} / \mathrm{kg})$, phenoxybenzamine $(2 \mathrm{mg} / \mathrm{kg})$, and metergoline $(1 \mathrm{mg} / \mathrm{kg})$ at high doses. Since neurochemical studies have demonstrated that TA-0910 reverses reduction in ACh turnover in the hippocampus and cerebral cortex of rats treated with pentobarbital (K. Kawashima, unpublished data), the antianesthetic action of TA-0910 may be derived from activation of cholinergic mechanisms. Our results are supported by a number of reports that the anti-anesthetic action of TRH is markedly suppressed by pretreatment with anti-cholinergic drugs in rodents $(4,7-9,20$, 21) and that suppression of the cholinergic activity by pentobarbital is antagonized by TRH in rats (22-24). From their findings that the anti-anesthetic action of TRH injected 
peripherally or into the posterior hypothalamic regions was markedly suppressed by intracerebroventricular or -hypothalamic pretreatment with atropine, atropine methyl bromide or hexamethonium but not by injection of these anti-cholinergic drugs into the midbrain reticular formation, Miyamoto et al. (9) presumed that the anti-anesthetic action of TRH may be mediated mainly via a cholinergic mechanism in the hypothalamus and partly via non-cholinergic neural mechanisms in other regions. However, in our present study, i.p. administration of physostigmine or oxotremorine alone or in combination with a low dose (0.01 mg $/ \mathrm{kg}$, i.v.) of TA-0910 did not show an anti-anesthetic action. Pentobarbital anesthesia was slightly suppressed by injection of carbachol into the posterior lateral hypothalamic area but not into any other site of the brain and rather enhanced by injection of the agent into the midbrain reticular formation, raphe nuclei, and locus ceruleus. Since the anti-anesthetic action of TRH and its analog MK-771 was not cancelled by reasonable doses of atropine or scopolamine, Santori et al. (12) excluded the possibility that there is a relationship between the enhancement of the cholinergic mechanism and the analeptic action of TRH. These findings suggest that the cholinergic mechanism does not play such an important role as has been reported in the antianesthetic actions of TA-0910 as well as TRH, and that the possibility of the involvement of other neurotransmitters such as DA, 5HT and NA must also be considered. Further studies are needed in this respect.

From the results obtained, TA-0910, like TRH, is considered to produce an anti-anesthetic action by action in a relatively selective manner on two activating systems, namely the posterior lateral hypothalamic area and the midbrain reticular formation, and the involvement of not only $\mathrm{ACh}$ but also other neurotransmitters including DA, 5HT, and NA should be examined for their anti-anesthetic action.

\section{REFERENCES}

1 Suzuki, M., Sugano, H., Matsumoto, K., Yamamura, M. and Ishida, R.: Synthesis and central nervous system actions of thyrotropin-releasing hormone analogues containing a dihydroorotic acid moiety. J. Med. Chem. 33, 2130-2137 (1990)

2 Yamamura, M., Kinoshita, K., Nakagawa, H., Tanaka, Y., Maeda, K. and Ishida, R.: Pharmacological study of TA-0910, A new thyrotropin-releasing hormone (TRH) analog, (I): Effects on the central nervous system by oral administration. Japan. J. Pharmacol. 53, $451-461$ (1990)

3 Havlicek, V., Rezek, M. and Friesen, H.: Somatostatin and thyrotropin-releasing hormone: Central effect on sleep and motor system. Pharmacol. Biochem. Behav. 4, 455-459 (1976)

4 Prange, A.J., Jr., Breese, G.R., Cott, J.M., Martin, B.R., Cooper, B.R., Wilson, I.C. and Plotnikoff, N.P.: Thyrotropin-releasing hormone: Antagonism of pentobarbital in rodents. Life Sci. 14, 447-455 (1974)

5 Andrews, J.S. and Sahgal, A.: The effects of thyrotropin-releasing hormone, metabolites and analogues on locomotor activity in rats. Regul. Pept. 7, 97-109 (1983)

6 Andry, D.K. and Horita, A.: Thyrotropin-releasing hormone: Physiological concomitants of behavioral excitation. Pharmacol. Biochem. Behav. 6, 55-59 (1977)

7 Nanumi, S., Nagai, Y. and Nagawa, Y.: Cholinergic mechanism in the antagonistic effect of thyrotropin-releasing hormone (TRH) on pentobarbital-induced sleep. Neurochem. Res. 6, 818 (1981)

8 Horita, A., Carino, M.A. and Chesnut, R.M.: Influence of thyrotropin releasing hormone (TRH) on drug-induced narcosis and hypothermia in rabbits. Psychopharmacology (Berlin) 49, 57-62 (1976)

9 Miyamoto, M., Nagai, Y., Narumi, S., Saji, Y. and Nagawa, Y.: TRH and its novel analog (DN1417): Antipentobarbital action and involvement of cholinergic mechanism. Pharmacol. Biochem. Behav. 17, 797-806 (1982)

10 Kalivas, P.W. and Horita, A.: Thyrotropin-releasing hormone: central site of action in antagonism of pentobarbital narcosis. Nature 278, 461-463 (1979)

11 Kalivas, P.W. and Horita, A.: Thyrotropin-releasing hormone: Neurogenesis of actions in the pentobarbital-narcotized rat. J. Pharmacol. Exp. Ther. 212, $203-210$ (1980)

12 Santori, E.M., Schmidt, D.E., Kalivas, P.W. and 
Horita, A.: Failure of muscarinic blockade to antagonize analepsis induced by thyrotropin-releas. ing hormone and MK-771 in the rat. Psychopharmacology (Berlin) 74, 13-16 (1981)

13 Pellegrino, L.J. and Cushman, A.J.: Stereotaxic Atlas of the Rat Brain. Appleton-Century-Crofts, New York (1967)

14 Breese, G.R., Cott, J.M., Cooper, B.R., Prange A.J., Lipton, M.A. and Plotnikff, N.P.: Effects of thyrotropin releasing hormone (TRH) on the actions of pentobarbital and other centrally acting drugs. J. Pharmacol. Exp. Ther. 193, 11-22 (1975)

15 Cott, J.M., Breese, G.R., Cooper, B.R., Barlow, T.S. and Prange, A.J., Jr.: Investigations into the mechanism of reduction of ethanol sleep by thyrotropin-releasing hormone (TRH). J. Pharmacol. Exp. Ther. 1\%, 594-604 (1976)

16 Carino, M.A., Smith, J.R., Weick, B.G. and Horita, A.: Effects of thyrotropin-releasing hormone (TRH) microinjected into various areas of conscious and pentobarbital-pretreated rabbits. Life Sci. 19, 1687-1692 (1978)

17 Elrod, S.V. and Leslie, S.W.: Acute and chronic effects of barbiturates on depolarization-induced calcium inflax into synaptosomes from rat brain regions. J. Pharmacol. Exp. Ther. 212, 131-136 (1980)

18 French, J.D., Verzeano, M. and Magoun, H.W.:
A neural basis of the anesthetic state. Arch. Neurol. Psychiatry 69, 519-529 (1953)

19 Bradley, P.B. and Key, B.J.: The effect of drugs on arousal responses produced by electrical stimulation of the reticular formation of the brain. Electroenceph. Clin. Neurophysiol. 10, 97-110 (1958)

20 Yarbrough, G.G.: Studies on the neuropharmacology of thyrotropin-releasing hormone (TRH) and a new TRH analogue. Eur. J. Pharmacol. 48, 1927 (1978)

21 Yarbrough, G.G.: Thyrotropin releasing hormone and CNS cholinergic neurons. Life Sci. 33, 111118 (1983)

22 Santori, E.M. and Schmidt, D.E.: Effects of MK771, a TRH analog, on pentobarbital-induced alterations of cholinergic parameters in discrete regions of rat brain. Regul. Peptides 1, 69-74 (1980)

23 Schmidt, D.E.: Effects of thyrotropin-releasing hormone (TRH) on pentobarbital-induced decrease in cholinergic neuronal activity. Psychopharmacol. Commun. 1, 469-473 (1977)

24 Narumi, S., Nagai, Y., Miyamoto, M. and Nagawa, Y.: Thyrotropin-releasing hormone (TRH) and its analog (DN-1417): Interaction with pentobarbital in choline uptake and acetylcholine synthesis of rat brain slices. Life Sci. 32, 16371645 (1983) 